\section{Environmental justice in the context of planning}

\author{
Bongane Ntiwane \& Johnny Coetzee
}

http://dx.doi.org/10.18820/2415-0495/trp72i1.7

Peer reviewed and revised March 2018

${ }^{*}$ The authors declared no conflict of interest for this title or article.

\begin{abstract}
In recent years, environmental justice has been central in many Social Sciences discourses; yet it has gained limited recognition in planning, particularly in spatial planning theories. The extent of environmental justice in planning theory remains unrecorded or subtle in planning research. This study evaluates planning theories against the criteria that constitute the dimensions of environmental justice. The results of the work reveal that planning theories generally incorporate environmental justice to a limited extent. The study recommends the introduction of a new environmental justice paradigm shift in planning to bridge the identified gap in planning theory and practice. Regarding planning practice, the study highlights the need for planners to apply the principles of environmental justice in planning to achieve fairness in distribution, recognition, participation, capability consideration, and effects in monitoring and evaluation.
\end{abstract}

Keywords: Environmental justice, planning, spatial planning, spatial planning theories, planning theories

\section{OMGEWINGSGEREGTIGHEID IN BEPLANNINGSKONTEKS}

Alhoewel dit weinig erkenning gekry het in beplanningsteorieë en meer bepaald ruimtelike beplanningsteorieë, het die konsep van omgewingsgeregtigheid onlangs sentraal toegetree tot menige diskoers in die Sosiale Wetenskappe. Die omvang van omgewingsgeregtigheid in beplanningsteoriëe blyk beperk te wees en is slegs subtiel te vinde in beplanningsnavorsing. Hierdie studie evalueer bestaande beplanningsteoriëe teenoor die kriteria wat omgewingsgeregtigheid omskryf. Die resultate van die studie toon dat omgewingsgeregtigheid slegs in 'n beperkte mate in beplanningsteorie omvat word. Die studie beveel aan dat 'n nuwe omgewegingsgeregtigheid-wending nodig is om die geïdentifiseerde gaping in beplanning te oorbrug. Verder benadruk die studie die noodsaaklikheid vir beplanningpraktisyns om die beginsels van omgewingsgeregtigheid toe te pas om sodoende regverdigheid in verdeling, erkenning, deelname, monitering en evaluering in beplanning te bereik.

Sleutelwoorde: Beplanning, beplanningsteorieë, omgewingsgeregtigheid, ruimtelike beplanning, ruimtelike beplanningsteorieë

\section{TOKAFATSO YA TIKOLOHO MOELELONG WA THERO/TOKISETSO}

Dilemong tsena, tokafatso ya tikoloho e bile bohlokwa dithutong tse ngata tsa saense ya botho, empa e fumane tlotla e nnyane/lekaneng therong/tokisetsong, haholoholo tsebong/ditheoring tsa thero/tokisetso ya sepakapaka. Tekanyo ya toka bakeng sa tikoloho tsebong/theoring ya thero/tokisetso e ntse e sa ngolwa fatshe kapa e tlasa dipatlisiso tsa thero/tokisetso. Thuto ena e hlahloba ditheori/ditsebo tsa thero/ tokisetso hodima mokgwa o bontshang ditekanyo tsa toka ya tikoloho. Diphetho tsa mosebetsi di bontsha hore ka kakaretso ditheori tsa thero/tokisetso, di kopanya toka ya tikoloho ho fihla sebakeng se itseng. Thuto ena e kgothalletsa thahiso ya phetoho e ntjha mohlaleng wa toka ya tikoloho therong/tokisetsong bakeng sa ho kwala sekgeo se bonweng theoring ya thero le ketso. Mabapi le ketso ya thero, thuso e hlahisa thoko ya bahlophisi tabeng ya ho sebedisa melaotheo ya toka ya tikoloho therong ya ho fumana tekatekano phanong, kamohelong, ho bankakarolo, kelohlokong ya bokgoni le ditshwaetso tsa tlhokomelo le thatlhobo.

\section{INTRODUCTION}

In recent years, environmental justice (EJ) has gained recognition from some scholars and experts beyond its initial focus on distribution. The extant literature argues that the primary conception of EJ began on distribution, but recently, it has experienced extension (widened) to incorporate other dimensions (Hamlin, 2008; Pedersen, 2011; Urkidi \& Walter, 2011). However, there is a paucity of literature that illustrates the existence of EJ in spatial planning theory and practice. It is crucial to understand $\mathrm{EJ}$ in the context of the first (rational or synopsis, incremental, mixed scanning, and so on) and second (advocacy, transactive, communicative, and so on) generation planning approaches. Planning theory evolved from technical orientation to communicative approaches that involve communities in planning. Hence, the need to comprehend EJ from the context of the aforementioned planning approaches. The first-generation planning approach comprises theories of planning that are procedural, yet expert driven. Conversely, the second-generation planning approach consists of theories in planning that are substantive, with more focus on deliberation and argumentation to address planning matters. These two approaches supplement and complement each other, as the latter arose to bridge the communication gap that existed in the former approach. Therefore, gauging the level of EJ in these theories is crucial.

This study first presents the literature on the dimensions of EJ and spatial planning practice/theories to provide practical and theoretical insight on the subject. Secondly, it discusses the research strategy that explains the methods applied in theory evaluation and analysis. Lastly, it discusses the study findings and conclusion. The results presented in the work show the gap in planning 
that influences the need for a new paradigm shift in EJ for planning theory and practice. The article concludes with the view that EJ in planning has the potential to shape planning theory and practice making it the third-generation approach to planning.

\section{THE MEANING OF ENVIRONMENTAL JUSTICE}

The exposition of the term 'environment' is crucial in leading towards the understanding of EJ. According to Van der Merwe (2009: 25), the vast majority of people define the environment in the context of wilderness and nature. Such definitions neglect to include or consider social equity. In support of the above argument, Moore and Wilson (2009: 2617) argue that there is a general ignorance of social equity in practice. In a court case between the Fuel Retailers Association of SA (Pty) Ltd v Director-General, Environmental Management Mpumalanga and Others (Case number CСТ67/06), regarding the establishment of a filling station where the government had issued an environmental authorization, the court in its ruling underscored the importance of socio-economic preconditions (Kotze, 2008). In its judgement of 7 June 2007 on the above case, the Constitutional Court of South Africa stated that environmental authorities are responsible for considering socio-economic factors as a part of an environmental obligation. This passage of the judgement emphasizes the importance of social equity in an environment.

In recent years, the developments in planning theory and practice have influenced the conception of the term 'environment' to assume attributes that outwit nature or wilderness in its context. Agyeman (2007: 172) states that the foci of the term nowadays incorporate "urban disinvestment, racism, homes, jobs, neighbourhood, and communities". On the other hand, Novotny (2000) presents the term 'environment' as simply representing where we live, play and work. Interestingly and as an extension to the term, Brownlie, Walmsley and Tarr (2006: 1) view the environment as including "all living organisms (plants, animals, and other life), the biophysical environment (land, water, and air), including social, economic and cultural conditions". This view incorporates wildlife, human beings, natural resources and socio-economic attributes. In the context of this study, the term 'environment' means a system that includes components and functions of natural capital (e.g., water, wetlands, soil, air, and land) with its wildlife, including the socio-economic and cultural conditions of human beings. This definition correlates with the description of environment as provided in the National Environmental Management Act, 1998 (Act No. 107 of 1998) (NEMA). This piece of legislation refers to the term environment as

the surroundings within which humans exist and that are made up of-

i. the land, water and atmosphere of the earth;

ii. micro-organisms, plant and animal life;

iii. any part or combination of (i) and (ii) and the interrelationships among and between them; and

iv. the physical, chemical, aesthetic and cultural properties and conditions of the foregoing that influence human health and well-being (RSA, 1998: 8).

The understanding of the term 'environment', therefore, necessitates the explanation of justice.

The concept of justice attracts different interpretations; however, central to its construct is fairness. Gleeson (1996: 229) states that justice relates to both "due legal procedures and social justice". The due legal procedures entail fairness of legal processes in all matters disposed of by legal authorities. On social justice, the concept consists of the equal fulfilment of the socioeconomic needs of humankind. More interestingly, Rawls (2001) refers to justice as fairness through liberties and the difference principle that prioritizes social equity among the marginalized group. The Rawls approach to justice is egalitarian, based on equality. More interestingly, the Japanese community considers justice as about "good versus evil", "unrealistic and naïve" (Fukuma, 2014: 891). The former reference to justice by the Japanese explicitly relates justice with ethics. Justice originates from the moral philosophy branch of normative ethics. The existing literature reveals that the normative ethics consist of consequentialism (utilitarian, and so on) (Stubbs, 1981; Howard-Snyder, 1994; Petersen, 2013), deontology (Kymlicka, 1988; Rawls, 2001), and virtue ethics (Gong \& Zhang, 2010; Dimmock \& Fisher, 2017). First, a consequentialist judges whether an action is ethical or not from examining its consequences. The common framework of consequentialism includes utilitarianism. This framework decides on whether an action is ethical or not through the aggregation of utility (Rawls, 2001) and state of welfare (Kymlicka, 1988; Petersen, 2013). On the other hand, a deontologist views the contravention of rules as wrong and unethical. For instance, the violation of constitutional rights is unethical under this ethics. Lastly, Gong and Zhang (2010) underscore that virtue ethics arose to challenge consequentialism and deontology. Virtue ethics are about the universal societal practice. These ethics emphasize each person's inherent responsibility toward the environment such as the duty of care.

In the extant literature, the United States of America's Environmental Protection Agency defines EJ in the context of procedural justice (PJ) and distributive justice (DJ) (Laurent, 2011: 1846), while the definition of the United Kingdom's Environment Agency views it with the dimension of procedural, distributive and policy justice (Laurent, 2011: 1848). These two definitions present $\mathrm{EJ}$ with three dimensions that address the flaws of the original EJ concept that became peculiar to distribution. However, the existing literature introduces other definitions that highlight the lenses of restorative 
(Fredericks, 2011; Conrad, 2011), substantive, precaution, fair redress and compensation (Millner, 2011), recognitive, corrective (Whyte, 2011) and capability (Schlosberg, 2013) approaches. These new lenses introduced the multiplicity or plurality of $E J$ in planning, decision-making, and implementation. By contrast, according to McDonald (2002), the South African Environmental Justice Networking Forum defines EJ as about socio-economic transformation towards a good quality of life. This definition excludes the EJ dimensions required to guide the process towards the intended purpose. In considering the various thoughts of the abovementioned scholars, EJ denotes the fair and equitable distribution of environmental resources, services and activities to everyone, regardless of social structure, through recognition and the capability approach (CA), thus providing equitable access to participation in appropriate procedures, with substantive means towards restorative processes and benefits. The definition illuminates distribution through criteria (recognition and the CA), while ensuring that there is fairness in gaining access to decisionmaking procedures and restoration processes. This definition through the CA and recognitive justice (RJ) incorporates the natural environment, as well as the socio-economic and cultural conditions of society. In light of this definition, EJ consists of six dimensions that comprise distribution, recognition, participation/ procedural, substantive, CA and just policy (JP). In practice, normative ethics guide the application of these dimensions. As a result, EJ could shape spatial planning theory. Spatial planning, in general, responds to spatial distribution of resources, services and activities, including their relationship. The application of EJ dimensions presents a potential to strengthen the achievement of spatial planning outcomes. The following section presents the dimension of EJ and spatial planning practice.

\section{DIMENSIONS OF ENVIRONMENTAL JUSTICE AND SPATIAL PLANNING PRACTICE}

\subsection{Distribution}

Distributive justice (DJ) is the first dimension as well as the original theme of EJ. This dimension entails the equal allocation of services, resources, and activities. According to Konow (2001: 162), it guides the assignment of economic benefits. However, the concept has influenced countries such as South Africa to remain spatially fragmented. In South Africa, spatial planning under the apartheid regime promoted planning that distributed industrial land uses alongside residential uses, thereby creating land-use incompatibility (Leonard \& Pelling, 2010: 138). The DJs of the apartheid policies remain visible in the country's geographies. In the United States of America (USA), the distribution of planning focuses more on urban areas than on the countryside (Sudonienè \& Matonienè, 2009). These practices undoubtedly result from the challenges that exist in this dimension. In the existing literature, DJ appears to be inadequate regarding socio-economic, geographical and sociocultural conditions (Schlosberg, 2004; Boone, 2008; Urkidi \& Walter, 2011). By implication, DJ fails to acknowledge the existence of inequalities. In addressing these disparities, Konow (2001) suggests principles that should inform distribution, which include accountability, need, compensation, and context.

\subsection{RECOGNITION}

Recognitive justice (RJ) is the second dimension of EJ. Whyte (2011: 200) argues that "recognitive justice requires that policies and programmes meet the standard of fairly considering and representing the cultures, values, and situations of all affected parties". By contrast, the DJ dimension fails to consider the unique context of planning areas. Schlosberg (2004: 520) underscores the point that, without RJ, inequalities in distribution will remain a challenge.
In principle, RJ aids in understanding the geographical conditions (need and context) of a planning area, which would inform decisions on the distribution of resources and activities. The failure to consider recognition in distribution is a sign of unknowability. Unknowability relates to the deliberate ignorance of the environmental conditions, among many others, that affect an area and to deliberate action that conceals the detection of these circumstances (Dotson \& Whyte, 2013). The injustice, particularly spatial, emanates from wilful ignorance of most of the factors that affect societies. In Europe, Kunzmann (2007) argues that spatial injustice persists in making the achievement of EJ a strenuous exercise. Interestingly, RJ can be adequately achieved through procedural justice (PJ). Accordingly, Schlosberg (2004; 2013) argues that RJ is not integral to procedural or DJs.

\subsection{PARTICIPATION/ PROCEDURAL}

Procedural justice is the third dimension of EJ. In the literature reviewed, $\mathrm{PJ}$ is about guidelines that inform the procedure for public participation in decision-making regarding the implementation of plans (Millner, 2011: 109; He \& Sikor, 2015: 260). In essence, PJ ensures that these plans (land-use plans and other programmes) incorporate recognitive aspects to influence distribution in planning and implementation. More central to this dimension is fairness in the participation of parties. However, in practice, there are countries where public participation is mandatory and those where it is not mandatory. According to Mason (2010) and Poncelet (2012), in Europe, public participation is enforceable through the Aarhus Convention (Mason, 2010: 10); in India, it is enforceable through Executive Order 13715 (Whyte, 2011: 200), and, in South Africa, it is enforceable through the planning and environmental laws. These laws include the Local Government: Municipal Systems Act No. 32 of 2000 (RSA, 2000), the Spatial Planning and Land Use 
Management Act No. 6 of 2013 (RSA, 2013), and the National Environmental Management Act No. 107 of 1998, to name a few. On the other hand, Alexander (2005) states that in Israel, in particular, the planning legislation does not provide public participation opportunities. Latin America follows a similar approach, specifically Esquel (Urkidi \& Walter, 2011). The failure to consider PJ as a mandatory requirement in policies or law results in the unfair distribution of resources and activities, as there is no $\mathrm{RJ}$ in the process. In South Africa, public participation in spatial planning (Connelly, 2010; Todes, Karam, Klug \& Malaza, 2010) and integrated development planning (Todes, 2004; Cash \& Swatuk, 2011) appear to be characterised by procedural injustices. Moreover, the criteria of $P J$ require more than public participation (representation). Accordingly, the criteria comprise "ethicality, representation, consistency, decision quality, impartiality and correctibility" (Tyler, 1988: 104-105). By implication, the above factors define the quality of the public participation process in planning. Nonetheless, the success of PJ depends on the existing institutions that are available to support participation. These institutions relate to the fourth dimension of EJ.

\subsection{Substantive}

The fourth dimension of EJ is substantive justice (SJ). According to Millner (2011: 190), SJ refers to the governance tools required and made available to capacitate the general public for participating in decision-making. These governance tools involve institutions that advocate for EJ, observing the public interest and the capacity-building of the public on their rights regarding planning and decision-making processes (Millner, 2011: 199). SJ is, therefore, a vehicle for PJ. There is a close relationship between these dimensions. For instance, without the tools for mobilizing public participation, there will be no $\mathrm{PJ}$, leading to a lack of RJ, thus resulting in unfair distribution. Hence, Solitare (2005) underscores the importance of capacitating the public about participation in planning.

\subsection{Capability approach}

The fifth dimension of $E J$ is the capability approach (CA). According to Sen (2009: 232), the CA is a "general approach that focuses on information about individual advantages judged on an opportunity, rather than a particular design for how a society should be organized". This dimension aids in assessing the depth of recognized conditions of society so as to inform distribution. It precisely determines the opportunities that an action provides to a community. According to Beyazit (2011), Sen's CA consists of components that include basic needs, capabilities, functioning, freedom, opportunities, and choices. These elements are essential for a good quality of life and relate more to the principles of distribution. However, in the absence of Sen's list of capabilities, Nussbaum (2001: 79) highlighted the list to include "life, bodily health, bodily integrity, senses, imagination and thoughts, emotions, practical reason, affiliation, other species, play, and control over one's environment". In effect, through public participation, RJ should highlight the level of these capabilities in society to inform interventions. Clark (2009: 585) states that the achievement of the "minimal level of each capability is fundamental to human dignity and decent human life that is human rights". Peeters, Dirix and Sterckx (2015: 490) propose the "capability threshold as including the focus on subsistence and survival". Planning practices and spatial planning, in particular, should at all times make efforts to ensure the integration of facilities, amenities and other conditions in human settlements that guarantee the minimal achievement of well-being. Peeters et al. (2015: 492) argued that, in realizing this threshold, there is a need to equally secure the social preconditions (i.e., enforcement of the policy, education), while sufficiently achieving the material conditions (i.e., transportation, facilities) that rely on the biophysical conditions (i.e., nature protection). By implication, the approach incorporates sustainability to guarantee a high quality of life, well-being, and human development. By contrast, the CA is criticised for its failure to consider inequalities in capability (Qizilbash, 1997), and for its lack of ability to deal with inequalities beyond the threshold of minimum capability (Clark, 2009).

\subsection{JUST POLICY}

The last dimension of $E J$ is a just policy (JP). This dimension emphasises the fair consideration of policy effects on planning outcomes during the phases of preparation, implementation, and enforcement. The UK Environment Agency, in its definition of EJ, incorporated $P J$ to account for the fundamental norms, standards, and principles of environmental policy with their effects on all members of society (Laurent, 2011). In considering the effects of policy decisions, Whyte (2011: 200) highlights the significance of corrective justice (CJ) that focuses on restorative justice (REJ) measures that ensure that fairness is achieved on adverse effects, such as whether environmental injustices are either likely to occur or are occurring. According to Conrad (2011), REJ entails the change of moral behaviour and actions and improving approaches to redress injustices. In this context, JP subsumes REJ and CJ into EJ. In the existing literature, Millner (2011) postulates that EJ should provide measures to improve the lives of those exposed to the brunt of environmental injustices. It is through JP that policymakers could introduce, influence and enforce measures to safeguard against environmental injustices. Fredericks (2011) suggested an attribute of evaluating the effects of restoration on policy implementation towards achieving EJ. In this light, JP advocates for policy measures that assess the effectiveness of policy implementation.

\section{SPATIAL PLANNING THEORIES}

Urban and regional planning encapsulates socio-economic and biophysical activities that aim at 
forecasting, controlling and regulating urban and regional development (Pinson, 2007). It provides principles for plan-making, public participation, and implementation, among many others. Hall and Tewdwr-Jones (2011: 3-5) define urban and regional planning in its conventional context as spatial or physical, inclusive, multicultural, multi-objective and multidimensional through the application of planning theory to produce and implement plans. The output of a plan in its construct highlights the point that urban and regional planning examines the orderly distribution of environmental activities (as defined in the study) to improve the well-being of urban and rural communities, for both the present and the future. The orderly distribution of activities reflects the distribution dimension of EJ that is inherent in planning, coupled with the recognition of other socio-economic and biophysical factors. The urban and regional planning theories direct the orientation of towns and introduce many planning models to guide the distribution and interaction of activities in space.

Currently, planning theory links planning processes (procedural) with frivolous consideration of societal factors (substantive) that are likely to have an impact on public planning. The work of Faludi contributes to the procedural notion of planning, due to its lack of the substantive perspective of planning (Archibugi, 2004). According to Alexander (1992: 8, cited in Archibugi, 2004: 431), substantive matters include human settlements, community facilities, health care services, economic development instruments, urban growth, zoning, the physical environment, and neighbourhood services. The procedural notion of planning includes theories such as the rational planning, incremental, and mixed scanning. In literature, the procedural planning framework focuses primarily on the rational process followed in plan-making and execution than the realization of outcomes (Abukhater, 2009: 66-68). In practice, planners apply knowledge from Natural Sciences (to assist in guiding the production of plans) and Social Sciences (to determine and understand the social effects of proposed plans) (Ferreira, Sykes \& Batey, 2009: 32). The later source of planning knowledge highlights the substantive planning perspective that includes the communicative, advocacy and transactive planning theories. Remarkably, in theory and practice, the planning theory has never faced a replacement theory, but rather the improvement from rationalcomprehensive planning to advocacy planning and communicative planning (Roy, 2011: 6). In supporting this argument, Pissourios (2013) argues that, in planning, the advent of a new school of thought does not permanently replace an existing theory.

\subsection{Rational planning theory}

Rational planning theory involves a step-by-step process for its application. Pissourios (2013: 85) summarises the stages of the step-by-step approach from literature as consisting of problem analysis and definition; formulation of a programme (strategic objectives); production of policy or plan alternatives; evaluation of identified options, and implementation, including monitoring and evaluation of selected plans. The theory adopts a top-down approach (Dodero, 2010: 1), due to its universal planning standard (step-by-step process) on how to plan and implement. According to Hudson, Galloway and Kaufman (1979: 387), the theory considers problems from the quantitative analysis (mathematical) point of view, using technical and objective methods such as cost-benefit analyses and forecasting tools that require expert inputs. In practice, not only technical indicators address planning challenges, but also other factors (social and political) influence planning. This theory is prevalent in the discipline of planning (ljeoma, 2007) and widely employed in municipal planning (Seasons, 2003, cited in Hostovsky, 2006: 382).

According to Hall and Tewdwr-Jones (2011), the public is central to planning; therefore, experts work with the public to produce responsive spatial planning policies and plans. This policy's technocratic approach forecloses social and political issues relevant to planning.

\subsection{Incremental planning theory}

Incremental planning is essentially the breaking down of the longterm planning horizon into smaller entities that are complete projects by themselves (Tillner, 2013: 419). The theory arose as an alternative to the rational comprehensive theory. Hudson et al. (1979: 398) assert that the theory was developed as a result of the substantial criticisms levelled against the rational planning theory. In practice, the theory introduced a process that permits plan implementation (short-term) while plan development is in progress. The theory promotes the consideration of goals together with the selection of policies, while allowing a few alternatives (disjointed incrementalism) based on experimentation at the decentralized level (Lindblom,1959) and preferences of power holders (simple incrementalism) (Lindblom, 1979: 519). By contrast, the rational planning theory advocates for long-term planning and the consideration of alternatives without limitations. The incremental approach is an attempt to solve immediate short-term problems, rather than seeking to realize a clear long-term objective (Bokland, 1993: 152). In short, the theory is about addressing the day-to-day societal challenges and problems in planning. The Essay UK (2013: online) holds to the notion that rational planning and incremental planning are not entirely different theories of planning. This articulation implies that rationality in this theory likewise informs decision-making on alternatives, more than experiential knowledge does.

\subsection{Mixed scanning theory}

In an attempt to bridge the gap between the rational and incremental planning approaches, Etzioni (1967) introduced the use of the mixed scanning theory (MST). According to Etzioni (1986), the term 'scanning' refers to the investigation, sorting, 
and interpretation of information in order to draw conclusions that could inform decision-making. This theory integrates both the rational planning and the incremental planning theories in its approach. Bokland (1993) argues that Etzioni views both integrated theories as not existing in isolation. In essence, the application of the theory posits that planning ought to consider current (incrementalism) and future (rational) requirements. To further illustrate the theory in practice, it enables the analysis of a broad area ("wide") and drawing of details for a specific portion ("zoom") within an identified broad environment (Etzioni, 1986: 8). In the context of South Africa, spatial development frameworks (SDF)-planning directive of an entire municipal area and precinct plans (local SDF)-planning directive of a specific area within a municipality are a good example of the mixed scanning application.

\subsection{Advocacy planning theory}

The theorist Davidoff developed this theory; he critiqued the rational comprehensive theory and called for plans to acknowledge the intensely political character of planning that lies hidden under the science of comprehensive rationality (Mäntysalo, 2005: online). The theory reacted to the marginalization of the sociopolitical issues in planning. Davidoff (1965: 332) introduced advocacy planning, calling on planners to advocate for the interests of the poor and minority groups in neighbourhood planning. The theory supports the Rawls JP that promotes socio-economic equity for the disadvantaged groups. Hence, Friedmann (2008) views planners as the champions of public interest. Peattie (1968) (in Hudson et al., 1979: 390) critiqued the theory for blocking plans without mobilizing and advocating for alternative plans. In practice and based on experience, advocacy planning is sometimes wrongly applied during Planning Tribunal hearings, where representatives of parties argue for blocking developments in the interest of competition. This type of practice is prevalent in shopping complex developments or malls disregarding the potential of the development to improve the lives of the poor through job creation. In addition, the drawback of the theory is that, in the absence of advocacy planners, the interests of the poor and the marginalized, among others, would suffer injustices.

\subsection{Transactive planning theory}

The transactive planning theory focuses on a particular group and its spatial context, rather than on planning for the unknown (Hudson et al., 1979: 388). In South Africa, the praxis of spatial planning encourages the development of local spatial development frameworks or precinct plans that focus on a given area. It is evident, in practice, that technical knowledge drives the development of these plans. The focus of the approach on a particular group and its context has a potential of promoting discrimination and exclusionary planning. Hence, the theory depends significantly on personal experience, knowledge, beliefs, and participation during the first phase in addressing social and other planning problems (Hudson et al., 1979). According to Friedmann (2011: 15), knowledge involves "processed knowledge" (technical) and "experiential knowledge" (tacit and soft). In planning, processed knowledge requires the projection of population, the calculation of demand capacity for engineering services, and the preparation of layout plans, among others, whereas experiential knowledge entails knowledge about a place (history, customs, culture, and so on), socio-economic challenges, and other experiences of residents. The theory closes the gap of exclusion created by the rational planning, incremental and mixed scanning theories. Although the theory presents a better alternative, its focus on a selected group presents challenges in a diverse society. Nonetheless, Friedmann (1973) introduced the theory to create a platform where technocrats and, by extension, planners with technical knowledge might engage, deliberate and agree with their clients (communities) on planning matters, based on soft and technical knowledge. Moreover, Friedmann (2011: 21-26) presents the theory as "mutual learning and life of dialogue". In the context of mutual learning, planners learn experiential knowledge from clients (communities), whereas clients learn technical knowledge from planners. This character of the theory is congruent with the DJ principles that Konow (2001) cited. For instance, that platform of engagement allows the planners to understand the needs and demands of the communities that planning affects to inform the distribution of activities, resources, and services.

\subsection{Communicative planning theory}

In the literature, communicative planning is the dominant (Roy, 2011; Watson, 2003; Allmendinger \& Tewdwr-Jones, 2002), popular (Sharma, Deswal \& John, 2009) and influential (Dobrucká, 2016) concept or paradigm in planning that has improved and evolved from the original planning theories such as the rational-comprehensive theory. The existing literature shows that, in recent years, the communicative paradigm shift has emerged as planning that is collaborative, deliberative, communicative, and argumentative, as well as being about debate and bargaining (Healey, 1992; Healey, 1993; Healey, 1997;

Fischer \& Forester, 1993; Forester, 1999; Muthoo, 2000). This theory promotes communication in planning with a broader society different from the construct of the advocacy and transactive theories. The foundation (the Habermas communication rationality and action) of these communicative typologies is similar; hence, the use of these conceptions is interchangeable. According to Roy (2015), the theory of communicative rationality and action that Habermas introduced posits that central to democracy is communication, deliberation, and argumentation among parties of different interests. Communication rationality promotes the reasoning 
of intersubjective understanding, communication, and argumentation than individual rationale oriented towards the conception of "subjectobject” (Healey, 1992: 151) without the influence of the capital owners and state power (Huxley, 2000). In practice, state drives planning and development, the ignorance of state power is a drawback. The exclusion of power and state in the approach encourages what the researcher calls a no-touch-and-feel approach, where one forecloses others from engaging in deliberations. It is a theory imbued with the principles of empowerment, consensus (Pugh, 2005; Roy, 2015), mutual understanding (Healey, 1992; Healey, 2003; Huxley, 2000), common good and equality (Roy, 2015), common interest (Muthoo, 2000), honesty, truth, and openness (Allmendinger \& Tewdwr-Jones, 2002). Pissourios (2013) revealed the theory rejecting planning standards because of its bottom-up approach and utterly rejecting analytical indicators. However, the theory will only reject analytical indicators if implemented in isolation of original planning theories, i.e., rational planning. Hence, the theory is about attaining change through understanding phenomena by way of communicative action, rather than by only exploring approaches to solving problems (March, 2010; Yingjie, de Roo \& Bin, 2013) through technical means.

\section{RESEARCH METHOD}

This study evaluates planning theories against the criteria that constitute the dimensions of EJ. A qualitative research approach was used; it is a type of design where the paradigm of ethics and value systems (known as axiology - that is, what do we believe is true?) (Heron \& Reason, 1997: 287) are used to establish criteria for comparison of similarities and differences in planning theories (Salminen \& Lehtinen, 1982: 88; Hudson et al., 1979: 391). According to Franklin (2013), a qualitative approach results in gathering conceptual data; yet it takes individual experiences and observations into account (Strauss \& Corbin, 1998). The problem with the approach is its subjective nature that focuses on personal views and attitudes towards EJ and planning theories, including practice. Nevertheless, the comparative approach remains relevant to examine differences and similarities between variables (Mills, Van de Bunt \& De Bruijn, 2006: 261).

This study draws from Hudson et al. (1979: 391) and Pissourios (2013: 88) and adopts comparative criteria to gauge the extent or adequacy of $\mathrm{EJ}$ in spatial planning theories (rational planning, incremental, mixed scanning, advocacy, transactive and communicative). Table 1 presents a simple list of EJ criteria based on the six dimensions of EJ that one might use for assessing the features and attributes of the various planning theories.

These criteria mentioned in Table 1 emanate from the debates on EJ (Tyler, 1988; Konow, 2001; Nussbaum, 2001; Schlosberg, 2004; Boone, 2008; Sen, 2009; Sudonienè \& Matonienè, 2009; Beyazit, 2011; Conrad, 2011; Fredericks, 2011; Laurent, 2011; Millner, 2011; Urkidi \& Walter, 2011; Whyte, 2011; He \& Sikor, 2015; Peeters et al., 2015).

The interpretation of the attributes of each spatial planning theory enabled the evaluation of each theory against the set criteria. The evaluation allocates scores for a criterion against a theory, in which (X) represents no incorporation, (-) represents limited incorporation, and $(\checkmark)$ represents full incorporation. First, the no incorporation score becomes allocated if a theory shows no features or attributes of a dimension. Secondly, the limited incorporation score is applicable if a theory has some of the components of a dimension. Lastly, the full incorporation score applies if a theory reflects all characteristics of a dimension.

\section{FINDINGS AND ANALYSIS}

Table 2 is an attempt to evaluate the six spatial planning theories against the list of criteria described in Table 1. The purpose of this comparison is to suggest $\mathrm{EJ}$ areas of no incorporation, limited incorporation and full incorporation among the various planning theories and the overall pattern of inclusion of EJ dimensions found in the planning theory taken as a whole.

Table 2 indicates that the firstgeneration planning approach, which includes the rational, incremental and mixed scanning planning theories, does not incorporate the dimension of DJ, RJ, PJ and SJ, including the CA, with a limited consideration of JP. The results show the second-generation planning approach with a better incorporation of EJ dimensions. Further, the EJ evaluation on this latter approach reveals the communicative theory with full incorporation of EJ, but shows no potential for JP, and limited potential for the CA. In general, these two approaches have limited incorporation of EJ. As a result, planning practice will persistently fail to yield planning outcomes that promote EJ. Tables 3 to 7 show the analysis of the results in Table 2 .

\subsection{Environmental justice in the rational planning theory}

The results in Table 2 show that rational planning theory overall does not show many characteristics of EJ. Table 3 shows the tabulated results of the rational planning theory in terms of the characteristics of EJ.

The rational planning theory, in its traditional form, is expert driven and excludes input from non-expert stakeholders. However, in modern planning, inclusive planning is a priority. The rational planning theory presents a construct that undermines social equity issues that could be adequately identified through an inclusive relation approach of engagement. In practice, planning happens in space and within a diverse society with different needs that should invariably form part of a planning team. In the context of justice, attaining fairness through this theory is uncertain, as it focuses more on the technical aspects of problems, thus foreclosing consideration of soft issues such as the social implications. Dodero (2010) points out that, in many places around the world, the application of this theory has contributed to planning failure resulting from the subtle recognition of social and 
Table 1: Planning theory evaluation criteria

\begin{tabular}{|l|l|}
\hline \multicolumn{1}{|c|}{ Criteria: EJ dimensions } & \multicolumn{1}{c|}{ Characteristics of criteria } \\
\hline Distributive justice (DJ) & Consideration of fair distribution \\
\hline Recognitive Justice (RJ) & Recognition of cultures, values, and situations including conditions (natural, socio-economic, cultural, and so on) \\
\hline Procedural Justice (PJ) or Public Participation (PP) & Meaningful and fair involvement of general public in processes \\
\hline Substantive justice (SJ) & Incorporation of means or tools to participation by all parties and to capacity-building and awareness \\
\hline Capability approach (CA) & Assessment of capabilities and sustainability \\
\hline Just policy (JP) & $\begin{array}{l}\text { Consideration of implementation measures, monitoring, as well as evaluation criteria and measures for } \\
\text { redressing injustices }\end{array}$ \\
\hline
\end{tabular}

Table 2: $\quad$ Extent of EJ in planning

\begin{tabular}{|c|c|c|c|c|c|c|c|c|}
\hline \multirow{2}{*}{ Planning approach } & \multirow{2}{*}{ Planning theory } & \multicolumn{7}{|c|}{ Criteria: Dimension of environmental justices } \\
\hline & & DJ & RJ & PJ or PP & SJ & CA & JP & Overall \\
\hline \multirow{3}{*}{ First generation } & Rational planning & $\mathrm{X}$ & $\mathrm{X}$ & $\mathrm{X}$ & $\mathrm{X}$ & $\mathrm{X}$ & - & $\mathrm{X}$ \\
\hline & Incremental & $x$ & $\mathrm{X}$ & $\mathrm{x}$ & $\mathrm{X}$ & $\mathrm{X}$ & - & $x$ \\
\hline & Mixed scanning & $x$ & $\mathrm{X}$ & $x$ & $\mathrm{X}$ & $\mathrm{X}$ & - & $\mathrm{x}$ \\
\hline \multirow{3}{*}{ Second generation } & Advocacy & - & - & - & - & - & - & - \\
\hline & Transactive & - & - & - & - & - & - & - \\
\hline & Communicative & $\sqrt{ }$ & $\sqrt{ }$ & $\checkmark$ & $\sqrt{ }$ & - & $x$ & $\checkmark$ \\
\hline
\end{tabular}

Key:

$\mathrm{X}$ (no incorporation)

- (limited incorporation)

$\checkmark$ (full incorporation)

Table 3: Extent of EJ in rational planning theory

\begin{tabular}{|c|c|}
\hline Criteria: EJ dimensions & Results in terms of the characteristics of criteria \\
\hline Distributive justice (DJ) & $\begin{array}{l}\text { The theory is unable to guarantee fair distribution, as all inputs are from technical experts } \\
\text { The theory presents the needs and demands of a receiving community through scientific means }\end{array}$ \\
\hline Recognitive justice (RJ) & $\begin{array}{l}\text { The inability of the theory to allow for the process of assessing a problem through understanding the } \\
\text { experiences, values, cultures, and circumstances of societies removes it as a tool for achieving RJ }\end{array}$ \\
\hline Procedural justice (PJ) or Public participation (PP) & $\begin{array}{l}\text { The expert orientation of the theory limits the participation of the general public, thereby rendering } \\
\text { it procedurally unjust. While it is necessary to acknowledge the relevance of expert knowledge and } \\
\text { experience in planning, the social implication of its application likewise deserves recognition } \\
\text { The theory tacitly assumes inequality through the explicit exclusion of non-expert parties } \\
\text { This theory introduced an authoritarian perspective where the voiceless remain suppressed. The voiceless } \\
\text { are the parties whose views and experiences are invisible }\end{array}$ \\
\hline Substantive justice (SJ) & $\begin{array}{l}\text { The issue that saliently perseveres in this theory is the absence of PJ features } \\
\text { The weakness of the theory in promoting participation illuminates its inability to advocate for SJ } \\
\text { The theory neglected to promote mutual learning among parties of distinct interests (cognoscenti and } \\
\text { non-experts) }\end{array}$ \\
\hline Capability approach (CA) & $\begin{array}{l}\text { The characteristics of the theory lack in the assessment of capabilities } \\
\text { The theory disregards the capability of an institution to apply it } \\
\text { The theory posits that all institutions, equally, have experts to apply the quantitative tools to address } \\
\text { problems. Regarding the CA, achieving justice requires the minimum fulfilment of capabilities }\end{array}$ \\
\hline Just policy (JP) & The theory, to a limited extent, incorporates JP in its stage of monitoring and evaluation. \\
\hline
\end{tabular}

Table 4: Extent of EJ in incremental planning/mixed scanning theory

\begin{tabular}{|c|c|}
\hline Criteria: EJ dimensions & Results in terms of the characteristics of criteria \\
\hline Distributive justice (DJ) & $\begin{array}{l}\text { The consideration of a few alternatives that the theory supports could lead to inequality in the } \\
\text { implementation of plans, particularly on distribution } \\
\text { The limited selection of alternatives has the potential to neglect the most required services, resources, and } \\
\text { activities } \\
\text { The technical approach supported in this theory promotes scientific distribution of services, resources, and } \\
\text { activities to a few areas or alternatives }\end{array}$ \\
\hline Recognitive justice (RJ) & $\begin{array}{l}\text { The notion of the simple incrementalism that allows for the selection of options on the preferences of power } \\
\text { holders has the potential to unfairly exclude alternatives that are beneficial to an inclusive social structure. } \\
\text { An inclusive social structure is a structure that includes those with power and those without power, those of } \\
\text { low-, medium- and high-income groups, males and females, those with disabilities, and various race, ethnic, } \\
\text { religious and cultural groups and other affiliations }\end{array}$ \\
\hline Procedural justice (PJ) or Public participation (PP) & $\begin{array}{l}\text { The theory is an extension of the rational planning theory that is expert-driven } \\
\text { The consideration of the interests and experiences of an influential group has the potential to focus the } \\
\text { distribution of resources and policy effects (benefits) to a single group }\end{array}$ \\
\hline Substantive justice (SJ) & The theory is indirectly not one of pro-SJ, as it fails to present clear platforms of public participation \\
\hline Capability approach (CA) & $\begin{array}{l}\text { Akin to rational planning, the technocratic approach ingrained in this theory excludes experiential input in the } \\
\text { selection of alternatives for short-term implementation } \\
\text { The theory offers limited options to explore the required capability to realize planning outcomes }\end{array}$ \\
\hline Just policy (JP) & $\begin{array}{l}\text { The limited number of alternatives has a potential to exclude options that address injustices } \\
\text { The theory is unable to allow the development of broad criteria to monitor and evaluate planning outcomes, } \\
\text { given its restriction on alternatives }\end{array}$ \\
\hline
\end{tabular}


cultural conditions in planning.

According to Whyte (2011: 200), in realizing $\mathrm{RJ}$, the policy planner must have knowledge of the experiences, values, conditions, and situations of various parties. According to Millner (2011: 194), the core of procedural justice is participation in the decision-making process. The absence of inclusive participation in the theory creates procedural injustices. In practice, plans created through this theory never succeed in implementation (Hudson et al., 1979: 392); yet the theory presents a stage of implementation in its formation. Further, the characteristics of the theory lack in the assessment of capabilities. The theory applies a biased approach on capability, as it identifies capability that technocrats have assessed. In practice, the theory ignores an opportunity of understanding the capability of a community to sustain a planned development. In addition, the theory disregards the capability of an institution to apply it (Lindblom, 1959). In the majority of cases, planning authorities and, in particular, municipalities have capacity challenges. For instance, Tilaki, Abdullah, Bahauddin \& Marzbali (2014) state that, in Iran, the inadequate human resources in municipalities affect the implementation of planning initiatives. As a result, the appropriate application of the theory remains an academic exercise that does not contribute to planning outcomes.

\subsection{Environmental justice in the incremental planning/mixed scanning theory}

Table 2 shows that the incremental planning/mixed scanning theory overall does not incorporate EJ dimensions. Table 4 shows the tabulated results of the incremental planning/mixed scanning theory in terms of the characteristics of EJ.

The incremental planning theory is about addressing the day-to-day societal challenges and problems in planning by breaking down the long-term planning horizon into smaller entities that are complete projects by themselves. The mixed scanning theory proposes RJ only by supporting the simultaneous implementation of both long- and short-term goals. However, the recognitive approach is not fair because of simple incrementalism that prioritizes selection by influence and supporting the decentralization of functions and power, but fails to present clear platforms of participation (Hudson et al., 1979; Lindblom, 1959). In the absence of leadership and ability to facilitate or influence change, the decentralization of planning will make it impossible for the implementation of this reactive type of planning (Miraftab, Silver \& Beard, 2008). The selection of a few alternatives advocated in this theory appears as the reason for questionable spatial distribution in many countries such as South Africa. Although existing literature argues that the application of planning theory and practice shows a widening gap (Abukhater, 2009; Pissourios, 2013), the application of this theory creates injustices in particular where planning prioritizes urban areas rather than the countryside. Fairness in this theory is questionable, as planning requires a process that is free of discrimination and allows equal treatment of all planning stakeholders. The theory of incremental or mixed scanning, without improvements, will remain a channel for planning injustices.

\subsection{Environmental justice in the advocacy planning}

As part of the second-generation planning approach, advocacy planning (Table 2) shows limited incorporation of EJ dimensions. Table 5 shows the tabulated results of the advocacy planning theory in terms of the characteristics of EJ.

The theory promotes fair distribution for the disadvantaged groups (the poor) without considering the implication on the well-off. Advocacy planning supports SJ by encouraging governance to influence decisionmaking in planning. According to Healey (2003: 107), the forms of governance process include "rational-technical process, top-down command-and-control practices, and bureaucratic rule-governed behaviour". The governance process requires the representation of various actors who compete, participate or coordinate in the process. These actions of the role players are congruent with the types of governance (competition, participation, and coordination) that Yingjie et al. (2013) have cited. The governance central to this theory contributes to its achievement of justice. Advocacy planners are more on the participative type of governance that aims to influence decisions of state (coordination) and capital owners (competition). Millner (2011) highlighted SJ as a governance tool for the general public to participate in decisionmaking. Therefore, by this theory, planners as advocates of the minorities in planning are, therefore, the governance tools for the participation of the general public. The theory enables a planner to test the capability of a plan or an institution (i.e., a municipality) to transform action into an outcome beneficial to the marginalized groups. By implication, the theory provides a planner with an opportunity to introduce strategies in plans that would address challenges of the disadvantaged groups. Advocacy planning calls for the development and implementation of multi-objective plans that consider multicultural and diverse interests, in particular, those of the minority rather than a unit plan. The theory provides an opportunity to an advocacy planner to evaluate the effects of plans on the poor to establish the position of influence. In this context, although with the challenge of attaining balance, the theory aids in achieving JP in the context of Rawls' principle that supports justice for the disadvantaged groups.

\subsection{Environmental justice in transactive planning}

The results in Table 2 illustrate that the transitional planning theory, as part of the second generation planning approach, has limited ability to achieve EJ. Table 6 shows the tabulated results of the theory in terms of the characteristics of EJ.

The transactive planning theory focuses on a particular group and its spatial context, rather than 
Table 5: Extent of EJ in the advocacy planning theory

\begin{tabular}{|c|c|}
\hline Criteria: EJ dimensions & Characteristics of criteria \\
\hline Distributive justice (DJ) & $\begin{array}{l}\text { The theory fails to promote balance on distribution, for it concentrates on the interests of the poor, excluding } \\
\text { those of the well-off people }\end{array}$ \\
\hline Recognitive justice (RJ) & $\begin{array}{l}\text { The theory, to a limited extent, incorporates RJs. } \\
\text { The theory only recognizes soft knowledge of targeted poor community within technical planning processes } \\
\text { with the exclusion of a broader society likely to be affected by planning or development } \\
\text { In terms of the planning of an area to advance a particular purpose, the theory does not require the } \\
\text { consideration of different factors, stakeholders, and surrounding environment that its intention could affect }\end{array}$ \\
\hline Procedural justice (PJ) or Public participation (PP) & $\begin{array}{l}\text { The theory, to a limited extent, incorporates PJs. } \\
\text { The theory allows the participation of those affected by planning or development. By implication, those with } \\
\text { interests in the planning become excluded in the process } \\
\text { The theory promotes impartiality, for it focuses on the interests of the poor }\end{array}$ \\
\hline Substantive justice (SJ) & $\begin{array}{l}\text { The theory, to a limited extent, incorporates SJ. } \\
\text { The theory only recognizes soft knowledge of targeted poor community within technical planning processes, } \\
\text { with the exclusion of a broader society likely to be affected by planning or development } \\
\text { The theory promotes governance. However, the governance process requires the representation of various } \\
\text { actors who compete, participate or coordinate in the process. The theory promotes the representation for } \\
\text { the poor }\end{array}$ \\
\hline Just policy (JP) & $\begin{array}{l}\text { The theory allows a planner to evaluate the effects of plans on the poor to establish the position of } \\
\text { influence. In this context, although with the challenge of attaining balance, the theory aids in achieving JP } \\
\text { for the disadvantaged groups }\end{array}$ \\
\hline
\end{tabular}

Table 6: Extent of EJ in transactive planning theory

\begin{tabular}{|l|l|}
\hline \multicolumn{1}{|c|}{ Criteria: EJ dimensions } & \multicolumn{1}{c|}{ Characteristics of criteria } \\
\hline Distributive justice (DJ) & $\begin{array}{l}\text { The theory presents an ability of fair distribution to a prioritized community, creating a bias element in its } \\
\text { application }\end{array}$ \\
\hline Recognitive justice (RJ) & $\begin{array}{l}\text { The theory only recognizes soft knowledge of targeted community within technical planning processes, with } \\
\text { the exclusion of a broader society likely to be affected by planning or development }\end{array}$ \\
\hline Procedural justice (PJ) or Public participation (PP) & $\begin{array}{l}\text { The theory promotes injustices by excluding stakeholders, other than the receiving community, that are } \\
\text { likely to suffer the effects of planning decisions. In this regard, the achievement of PJ is partial } \\
\text { The approach partially achieves PJ through its involvement of only two primary stakeholders (planner and } \\
\text { client) in planning }\end{array}$ \\
\hline Substantive justice (SJ) & $\begin{array}{l}\text { The theory only provides a governance platform to an affected community or client } \\
\text { Capability approach (CA) } \\
\text { of capabilities. In this regard, the selective engagement identifies and determines only the capabilities of the } \\
\text { implementing agent or authorities and those of the receiving communities } \\
\text { With this theory, the CA could somehow succeed, for it would allow the mutual understanding between a } \\
\text { planner and client on the capabilities of a proposed plan to meet the needs of a community (client), yet its } \\
\text { limitation }\end{array}$ \\
\hline Just policy (JP) & $\begin{array}{l}\text { The theory, in its raw nature, cannot lead to JP, as its focus is not inclusive, but responsive to a client, } \\
\text { without taking into account the effects of planning in a broader contextual study }\end{array}$ \\
\hline
\end{tabular}

Table 7: Extent of environmental justice in communicative planning theory

\begin{tabular}{|l|l|}
\hline \multicolumn{1}{|c|}{ Criteria: EJ dimensions } & \multicolumn{1}{c|}{ Characteristics of criteria } \\
\hline Distributive justice (DJ) & By implication, the approach has the potential to improve distribution or to worsen inequalities \\
\hline Recognitive justice (RJ) & $\begin{array}{l}\text { The all-inclusive participation approach that the theory promotes makes it ideal to achieve RJ; yet it } \\
\text { challenges the Habermas foundation }\end{array}$ \\
\hline Procedural justice (PJ) or Public participation (PP) & $\begin{array}{l}\text { This theory promotes public involvement that is primary in PJ } \\
\text { The exclusion of power and the state in its approach creates PJs, thereby compromising its ability to } \\
\text { achieve full justice. }\end{array}$ \\
\hline Substantive justice (SJ) & $\begin{array}{l}\text { The theory does promote SJ through the processes of empowerment and consensus-building. It is through } \\
\text { deliberative and argumentative means that the experiential evidence of parties becomes known, leading to } \\
\text { the attainment of RJ. }\end{array}$ \\
\hline Capability approach (CA) & $\begin{array}{l}\text { The notion of excluding predetermined interests and identities presents the theory with patent features of } \\
\text { the CA that focus on individual judgements, rather than on preconceived ideas } \\
\text { It would be contrarious for the theory to address preconditions (social, biophysical and material) to } \\
\text { capabilities, as these would mostly require the actions of outside forces (state and other actors with power) }\end{array}$ \\
\hline Just policy (JP) & $\begin{array}{l}\text { The theory has no potential to achieve JP because of its communication rationality foundation. The } \\
\text { achievement of JP requires the consideration of the effects that those with power and without power bring } \\
\text { in shaping space. In the context of the theory, the engagement or deliberation from no basis foundation } \\
\text { (baseline) could lead to unsuccessful monitoring and evaluation }\end{array}$ \\
\hline
\end{tabular}


on planning for the unknown.

Therefore, this theory only addresses justice partially, but the platform of engagement with communities allows for the DJ principles suggested by Konow (2001). The fundamental values of transactive planning theory that advocates for engagement between the technocrat and community provide an opportunity to understand context, needs of the community, level of delivery (compensation) and its ability to influence change (accountability). However, the analysis focuses on the targeted planning area overlooking the surrounding planning drivers. In planning, without adequate capabilities to realize outcomes, the achievement of distribution and recognition is tantamount to planning for failure. The theory facilitates the assessment of capabilities, yet to a restricted client or community. In practice, planning involves many sectors; the exclusion of which renders planning implementation difficult. JP requires the monitoring and evaluation of planning effects on a receiving community and its surroundings. This theory exclusively promotes the achievement of JP within a given society, but ignores the surrounding.

\subsection{Environmental justice in the communicative planning}

Table 2 shows that the communicative planning theory fully incorporates the four dimensions (DJ, RJ, PJ and SJ) of EJ. The results illustrate a greater performance of EJ compared to the other theories. Table 7 shows the tabulated results of the communicative planning theory in terms of the characteristics of EJ.

The communicative approach advocates for deliberation, argumentation and consensusbuilding in planning among stakeholders with various interests. By implication, fair distribution is possible. However, the theory has a potential to worsen inequalities, because, in the majority of countries, the state initiates planning. In practice, planners assume the facilitation role in the process, yet with double standards. The first standard is that of an advocate of the powerful and the state, and the other standard is that of common good presenting neutrality. Accordingly, in spatial planning, planners have the role of facilitating democratic deliberation in order to foster spatial transformation and reaching of consensus (March, 2010; Cheng, 2013; Roy, 2015), while capacitating and empowering communities (Hostovsky, 2006; Brand \& Gaffikin, 2007). Conversely, in practice, planners are not always neutral, as they advocate for the interests of the state and those of their employers. For example, where the interests of the state are against spatial parity, which has been the case of the apartheid regime, the opposite is likely to happen. The theory supports a bottom-up approach different to the rational planning, incremental, and mixed scanning theories that employ a top-down approach. The bottom-up approach enables the theory to promote RJ, PJ and SJ. The communicative approach that the theory introduces is the basis for its outstanding performance on EJ. Although this approach became evident in the advocacy and transactive theories, it presented limitations. However, the communicative theory is different to other theories, for it presents no framework for its application concerning stages and does not set predetermined conditions and influence from any parties when stakeholders engage or deliberate in the planning process. In this regard, the exclusion of power and the state in this approach creates procedural injustices, thereby compromising its ability to achieve full justice. In practice, the state and developers often influence the direction of actions. The communicative rationality, as a foundation of this theory, would make it cumbersome to understand the capability of municipalities to deliver planning outcomes. Further, monitoring and evaluation require baselines. Therefore, the rejection of preconditions restricts full implementation of JP requirements.

\section{DISCUSSION}

The findings demonstrate that planning theories, in isolation or in combination, lack full incorporation of EJ. Planning theory is the foundation for planning practice and requires improvement in order to realize EJ. In the analysis, it became apparent that the communicative theory presents a better ability to achieve EJ, albeit with its challenges on the EJ dimension of JP and CA. The identified shortfall of planning theories concerning justice, therefore, encourages the introduction of EJ as a new paradigm shift in planning. This new paradigm shift in planning is undoubtedly the third-generation approach of planning that incorporates justice in objectivity (technical) approaches and subjectivity (communicative) approaches. In recent years, the focus in planning is beyond communicative approaches and attempts to address issues of justice. Although EJ gained recognition decades ago, planning has not yet fully adopted it as a concept. However, in recent years, the extant dearth in the literature has evolved to introduce, debate and address justice in planning (Spirn, 2005; Salkin, 2006; Arnold, 2007; Stanley, 2009; Byrne \& MacCallum, 2013; Madden, 2014; Ling, 2015; Basta, 2016), although in a different or restricted context. Undoubtedly, there is a need to introduce fairness in distribution, recognition of conditions, participation or procedures, and consideration of capabilities and effects. This need derives from the existing injustices that remain visible in spatial geographies of many countries such as South Africa. These injustices confirm that current planning theories are inadequate to influence practice. Further, this planning approach intends to address the widening gap between planning theory and practice that Pissourios (2013) has revealed.

\subsection{Environmental justices and paradigm shift in planning theory}

Incorporating EJ in planning is more of an extension of the existing planning theories than a theory shift. In the literature, some scholars 
initiated the introduction of EJ in planning, but without full alignment with the EJ dimensions. Arnold (2007) identified 18 principles of EJ planning. These principles, in a broad and summarized context, include the equal distribution of activities (policies, infrastructure, land uses, and so on), contextual recognition and audit, involvement of all parties, prioritization of the least advantaged people in planning and development, protection of nature (pollution, degradation) and society (from gentrification, exclusion, health hazard, and so on), and promotion of compatible land uses. The principles that Arnold propounded underscore the new turn of planning that promotes equality in planning the environment. Nonetheless, these principles only consider issues that address the DJ, PJ, RJ and JP dimensions of $E J$, with the exclusion of the CA and SJ. In expanding the work of Arnold, the researcher, therefore, reframes the EJ principles as follows:

a. Achieve a just distribution of activities in space, based on an audit of EJ that considers the need, compatibility, accountability, compensation, and context.

b. Promote the participation of all members of the society through the adoption of governance platforms and processes.

c. Promote and recognize diverse knowledge (experiential and expert) equally in planning and implementation processes.

d. Consider the capability of the environment, state organizations and the general public that the planning affects, so as to achieve planning goals and outcomes.

e. Support fair planning policies, strategies, programmes, and laws that promote the improvement of the quality of life for all.

These principles are consistent with the dimensions of EJ discussed in the above sections of the study. In light of the above principles, the propositions of the EJ planning approach include the notion of spatial planning as a:

a. Just distributive action (DJ) that considers fairness in the distribution of activities, services and resources, on the basis of needs and context.

b. Multi-stakeholder democratic planning procedure (PJ) that involves all stakeholders in the planning and implementation process, regardless of social structure and power, thereby providing equal access to deliberation, information and consensus-building.

c. Contextual experience and learning process $(\mathrm{RJ})$ that allows inclusiveness of all conditions that define and contribute to good quality of life.

d. Vehicle for governance (SJ), providing platforms for every stakeholder to equally access, communicate and collaborate on planning-related matters and decisions.

e. An action for capability assessment (CA) that allows for the recognition of expert and experiential knowledge on the opportunities available in the environment (natural, cultural, socio-economic and state capability) to improve the quality of life.

f. Environmentally restorative approach (JP) that centralizes effects, monitoring and evaluation throughout the planning process (inception to implementation) to ensure fair distribution of spatial transformation and quality of life.

g. In practice and literature, these lenses exist dependently or independently; yet the framework of the EJ planning approach has not categorically classified these within its approach. Unquestionably, there is a dearth of literature on $\mathrm{EJ}$ in planning; hence, the proposal of this new thought and lexicon of planning. There is, however, a need for further research to explore whether planners would accept the EJ planning approach.

\section{CONCLUSION}

This study reveals the limited exposure of EJ in spatial planning theory, resulting in the introduction of the third-generation approach that incorporates $\mathrm{EJ}$ in planning. The implication of this study on planning theory is that the development of planning theory should consider the dimensions of EJ in context and application. Further, it is suggested that planning education reviews its curriculum to incorporate $\mathrm{EJ}$ at an entrance phase of planning programmes. The study's implications on planning practice are in planning and policy in respect of the fair distribution of activities, services, and resources. The study presents the need for planners to equally recognize expert and experiential knowledge in spatial planning. The study highlights the importance of fairness rather than only meaningfulness in public participation processes involved in spatial planning. In this context, planners ought to safeguard against biases on stakeholder involvement and participation when preparing plans. The study further introduces new principles that planners could adopt in plan preparation and implementation. By implication, the introduction of EJ in planning has the potential to shape spatial planning theory and practice.

\section{REFERENCES}

ABUKHATER, A.B. 2009. Rethinking planning theory and practice: A glimmer of light for prospects of integrated planning to combat complex urban realities. Theoretical and Empirical Researches in Urban Management, 4(2), pp. 64-79.

AGYEMAN, J. 2007. Environmental justice and sustainability. In: Atkinson, G., Dietz, S. \& Neumayer, E. (Eds). Handbook of sustainable development. Cheltenham: Edward Elgar, pp. 171-188. https://doi. org/10.4337/9781847205223.00020

ALEXANDER, E.R. 2005. Institutional transformation and planning: From institutionalization theory to institutional design. Planning Theory, 4(3), pp. 209-223. https://doi. org/10.1177/1473095205058494

ALLMENDINGER, P. \& TEWDWRJONES, M. 2002. The communicative turn in urban planning: Unravelling paradigmatic, imperialistic and moralistic dimensions. Space and Polity, 6(1), pp. 5-24. https://doi. org/10.1080/13562570220137871 
ARCHIBUGI, F. 2004. Planning theory: Reconstruction or requiem for planning? European Planning Studies, 12(2), pp. 425-445. https://doi. org/10.1080/0965431042000194994

ARNOLD, T. 2007. Planning for environmental justice. Planning \& Environmental Law, 59(3), pp. 3-12. https://doi.org/10.1080/15480755.2007 .10394433

BASTA, C. 2016. From justice in planning towards planning for justice: A capability approach. Planning Theory, 15(2), pp. 190-212. https://doi. org/10.1177/1473095215571399

BEYAZIT, E. 2011. Evaluating social justice in transport: Lessons to be learned from the capability approach. Transport Review, 31(1), pp. 117-134. https://doi.org/10.1080/01441647.2010 .504900

BOKLAND, H. 1993. Planning in Dutch cultural policy: An attempt at mixed scanning. Acta Politica, 28(2), pp. 151-170.

BOONE, C.G. 2008. Environmental justice as process and new avenue for research. Environmental Justice, 1(3), pp. 149-153. https://doi.org/10.1089/ env.2008.0530

BRAND, R. \& GAFFIN, F. 2007. Collaborative planning in an uncollaborative world. Planning Theory, 6(3), pp. 282-313. https://doi. org/10.1177/1473095207082036

BROWNLIE, S., WALMSLEY, B. \& TARR, P. 2006. Guidance document on biodiversity, impact assessment and decision making in Southern Africa. The Southern African Institute for Environmental Assessment.

BYRNE, J. \& MACCALLUM, G. 2013. Bordering on neglect: 'Environmental justice' in Australian planning.

Australian Planner, 50(2), pp. 164-173. https://doi.org/10.1080/07293682.2013 .776984

CASH, C. \& SWATUK, L. 2011. Integrated development planning in South Africa: Lessons from the Dwars River Valley. Urban Forum, 22(1), pp. 53-73.

CHENG, Y. 2013. Collaborative planning in the network: Consensus seeking in urban planning issues on the Internet - the case of China. Planning Theory, 12(4), pp. 351-368. https://doi. org/10.1177/1473095213499655

CLARK, J.P. 2009. Capabilities theory and the limits of liberal justice: On Nussbaum's Frontier of justice.
Human Rights Revision, 10(4), pp. 583-604. https://doi.org/10.1007/ s12142-008-0109-8

CONNELLY, S. 2010. Participation in a hostile state: How do planners act to shape public engagement in politically difficult environments? Planning Practice and Research, 25(3), pp. 333-351. https://doi.org/10.1080/02697 459.2010.503427

CONRAD, S.M. 2011. A restorative environmental justice for prison e-waste recycling. Peace Review: A Journal of Social Justice, 23(3), pp. 348-355.

DAVIDOFF, P. 1965. Advocacy and pluralism in planning. Journal of the American Institute of Planners, 31(4), pp. 331-338. https://doi. org/10.1080/01944366508978187

DIMMOCK, M. \& FISHER, A. 2017. Ethics for A-level. Cambridge: Open Book Publishers. https://doi. org/10.11647/OBP.0125

DOBRUCKÁ, L. 2016. Reframing planning theory in terms of five categories of questions. Planning Theory, 15(2), pp. 145-161. https://doi. org/10.1177/1473095214525392

DODERO, A.C. 2010. An analysis of the rational comprehensive model in selected cities in developing countries. Revista Observatorio Calasanz, 1(3), pp. 171-181.

DOTSON, K. \& WHYTE, K. 2013. Environmental justice, unknowability and unqualified affectability. Ethics and the Environment, 18(2), pp. 55-79. https://doi.org/10.2979/ ethicsenviro.18.2.55

ESSAY, UK. 2013. Planning theory in city development. [Online]. Available at: <https://www.ukessays.com/ essays/design/planning-theory-in-citydevelopment. php?cref=1> [Accessed: 24 October 2016].

ETZIONI, A. 1967. Mixed scanning: A third approach to decision making. Public Administration Review, 27(5), pp. 385-392. https://doi. org/10.2307/973394

ETZIONI, A. 1986. Mixed scanning revisited. Public Administration Review, 46(1), pp. 8-14. https://doi. org/10.2307/975437

FERREIRA, A., SYKES, O. \& BATEY, P. 2009. Planning theory or planning theories? The hydra model and its implications for planning education. Journal for Education in the Built Environment, 4(2), pp. 29-54. https:// doi.org/10.11120/jebe.2009.04020029
FISCHER, F. \& FORESTER, J.

(Eds). 1993. The argumentative turn in policy analysis and planning. London: UCL Press. https://doi. org/10.1215/9780822381815

FORESTER, J. 1999. The deliberative practitioner: Encouraging participatory planning processes. London: MIT Press.

FRANKLIN, M.I. 2013. Understanding research: Coping with the quantitativequalitative divide. London: Routledge.

FREDERICKS, S.E. 2011. Monitoring environmental justice. Environmental Justice, 4(1), pp. 63-69.

FRIEDMANN, J. 1973. Retracking America: A theory of transactive planning. Garden City, NY: Anchor/ Doubleday.

FRIEDMANN, J. 2008. The uses of planning theory: A bibliographic essay. Journal of Planning Education and Research, 28(2), pp. 247-257. https:// doi.org/10.1177/0739456X08325220

FRIEDMANN, J. 2011. Insurgencies: Essays in planning theory. London: Routledge.

FUKUMA, S. 2014. A brief sketch of the reception of John Rawls' philosophy. Philosophy East and West, 64(4), pp. 887-901. https://doi.org/10.1353/ pew.2014.0062

GLEESON, B. 1996. Justifying justice. Area, 28(2), pp. 229-234.

GONG, Q. \& ZHANG, L. 2010. Virtue ethics and modern society - A response to the thesis of the modern predicament of virtue ethics. Frontiers of Philosophy in China, 5(2), pp. 255-265.

HALL, P. \& TEWDWR-JONES, M. 2011. Urban and regional planning. $5^{\text {th }}$ edition. London: Routledge.

HAMLIN, C. 2008. Is all justice environmental? Environmental Justice, 1(3), pp. 145-147. https://doi. org/10.1089/env.2008.0533

HE, J. \& SIKOR, T. 2015. Notions of justice in payments for ecosystem services: Insights from China's Sloping Land Conversion Program in Yunnan Province. Land Use Policy, 43(1), pp. 207-216. https://doi.org/10.1016/j. landusepol.2014.11.011

HEALEY, P. 1992. Planning through debate: The communicative turn in planning theory. The Town Planning Review, 63(2), pp. 143-162. https://doi.org/10.3828/ tpr.63.2.422x602303814821 
HEALEY, P. 1993. The communicative work of development plans. Environment and Planning $B, 20$, pp. 83-104. https://doi.org/10.1068/ b200083

\section{HEALEY, P. 1997. Collaborative planning: Shaping places in fragmented societies. London: Palgrave Macmillan. https://doi. org/10.1007/978-1-349-25538-2}

HEALEY, P. 2003. Collaborative planning in perspective. Planning Theory, 2(2), pp. 101-123. https://doi. org/10.1177/14730952030022002

HERON, J. \& REASON, P. 1997. A participatory inquiry paradigm. Qualitative Inquiry, 3(3), pp. 274-294. https://doi. org/10.1177/107780049700300302

HOSTOVSKY, C. 2006. The paradox of the rational comprehensive model of planning. Journal of Planning Education and Research, 25(4), pp. 382-395. https://doi. org/10.1177/0739456X05282831

HOWARD-SNYDER, F. 1994. The heart of consequentialism. An International Journal for Philosophy in the Analytic Tradition, 76(1), pp. 107-129. https:// doi.org/10.1007/BF00989722

HUDSON, B.M., GALLOWAY, T.D. \& KAUFMAN, J.L. 1979. Comparison of current planning theories: Counterparts and contradictions. Journal of the American Planning Association, 45(4), pp. 387-398. https://doi. org/10.1080/01944367908976980

HUXLEY, M. 2000. The limits to communicative planning. Journal of Planning Education and Research, 19(4), pp. 369-377. https://doi. org/10.1177/0739456X0001900406

IJEOMA, E.O.C. 2007. Rationality, disjointed incrementalism and mix scanning theories for decision-making on globalisation. Journal of Public Administration, 42(8), pp. 816-829.

KONOW, J. 2001. Fair and square: The four sides of distributive justice. Journal of Economic Behavior \& Organization, 46(2), pp. 137-164. https://doi. org/10.1016/S0167-2681(01)00194-9

KOTZE, L.J. 2008. South African environmental law through the cases. Durban: LexisNexis.

KUNZMANN, K.R. 2007. Planning for spatial equity in Europe. International Planning Studies, 3(1), pp. 101-120. https://doi. org/10.1080/13563479808721701
KYMLICKA, W. 1988. Rawls on teleology and deontology. Philosophy \& Public Affairs, 17(3), pp. 173-190.

LAURENT, E. 2011. Issues in environmental justice within the European Union. Ecological Economics, 70(11), pp. 18461853. https://doi.org/10.1016/j. ecolecon.2011.06.025

LEONARD, L. \& PELLING, M. 2010. Mobilisation and protest: Environmental justice in Durban, South Africa. Local Environment, 15(2), pp. 137-151. https://doi. org/10.1080/13549830903527654

LINDBLOM, C.E. 1959. The intelligence of democracy. Decision making through mutual adjustment. New York: The Free Press.

LINDBLOM, C.E. 1979. Still muddling, not yet through. Public Administration Review, 39(6), pp. 517-526. https://doi. org/10.2307/976178

LING, W. 2015. Urban renewal and spatial justice in China's changing urban governance. Canadian Social Science, 11(8), pp. 11-15.

MADDEN, L.A. 2014. Rights to the city and spatial justice: The search for social justice in post-1970 Long Beach. M. thesis. California State University, Long Beach.

MÄNTYSALO, R. 2005. Approaches to participation in urban planning theories. [Online]. Available at: <http://ozgol. mytehran.ir/portals/0102/documents/ Approaches $\% 20$ to $\% 20$ Participation $\% 20$ in\%20Urban\%20Planning\%20Theories. pdf > [Accessed: 19 October 2016].

MARCH, A. 2010. Practising theory: When theory affects urban planning. Planning Theory, 9(2), pp. 108-125. https://doi. org/10.1177/1473095209357864

MASON, M. 2010. Information disclosure and environmental rights: The Aarhus Convention. Global Environmental Politics, 10(3), pp. 10-31. https://doi.org/10.1162/ GLEP_a_00012

MCDONALD, D.A. 2002. Environmental justice in South Africa. Cape Town: University of Cape Town Press.

MILLNER, F. 2011. Access to environmental justice. Deakin Law Review, 16(1), pp. 189-207. https://doi. org/10.21153/dlr2011vol16no1art99

MILLS, M., VAN DE BUNT, G.G. \& DE BRUIJN, J. 2006. Comparative research: Persistent problems and promising solutions. International
Sociology, 21(5), pp. 619-631. https:// doi.org/10.1177/0268580906067833

MIRAFTAB, F., SILVER, C. \& BEARD, V.A. 2008. Situating contested notions of decentralized planning in the Global South. In: Beard, V.A., Miraftab, F. \& Silver, C. (Eds). Planning and decentralization: Contested spaces for public action in the Global South. New York: Routledge, pp. 1-18.

MOORE, S.A. \& WILSON, B.B. 2009. Contested construction of green building codes in North America: The case of the Alley Flat Initiative. Urban Studies, 46(12), pp. 2617-2641. https:// doi.org/10.1177/0042098009346327

MUTHOO, A. 2000. A non-technical introduction to bargaining theory. World Economics, 1(2), pp. 145-166.

NOVOTNY, P. 2000. Where we live, work and play. Westport, Connecticut: Praeger.

NUSSBAUM, M.C. 2001. Women and development: The capabilities approach. Cambridge: Cambridge University Press.

PEDERSEN, O.W. 2011. Environmental justice in the UK: Uncertainty, ambiguity and the law. Legal Studies, 31(2), pp. 279-304. https://doi. org/10.1111/j.1748-121X.2010.00185.X

PEETERS, W., DIRIX, J. \& STERCKX, S. 2015. Towards an integration of the ecological space paradigm and the capabilities approach. Journal of Agricultural Environmental Ethics, 28(3), pp. 479-496. https://doi. org/10.1007/s10806-014-9498-7

PETERSEN, S. 2013. Utilitarian epistemology. Synthese, 190(6), pp. 1173-1184. https://doi.org/10.1007/ s11229-011-9887-7

PINSON, G. 2007. Urban and regional planning. In: Bevir, M. (Ed.). Encyclopedia of governance, Volume 2. Thousand Oaks, California: Sage, pp. 1005-1007. https://doi. org/10.4135/9781412952613.n559

PISSOURIOS, I.A. 2013. Whither the planning theory-practice gap? A case study on the relationship between urban indicators and planning theories. Theoretical and Empirical Researches in Urban Management, 8(2), pp. 80-92.

PONCELET, C. 2012. Case study access to justice in environmental matters: Recent developments. International Community Law Review, 14(2), pp. 179-185. https://doi. org/10.1163/187197312X633487

PUGH, J. 2005. The disciplinary effects of communicative planning in Soufrière, 
St Lucia: Governmentality, hegemony and space-time-politics. Transactions of the Institute of British Geographers, 30(3), pp. 307-322. https://doi. org/10.1111/j.1475-5661.2005.00173.x

QIZILBASH, M. 1997. Policy arena: A weakness of the capability approach with respect to gender justice. Journal of International Development, 9(2), pp. 251-262. https://doi.org/10.1002/ (SICI)1099-1328(199703)9:2<251::AIDJID437>3.0.CO;2-Q

RAWLS, J. 2001. Justice as fairness: A restatement. London: Howard University Press.

ROY, A. 2011. Urbanisms, worlding practices and theory of planning. Planning Theory, 10(1), pp. 6-15. https://doi. org/10.1177/1473095210386065

ROY, P. 2015. Collaborative planning a neoliberal strategy? A study of Atlanta Beltline. Cities, 43, pp. 59-68. https:// doi.org/10.1016/j.cities.2014.11.010

RSA (REPUBLIC OF SOUTH AFRICA). 1998. National Environmental Management Act, Act 107 of 1998. Pretoria: Government Printers.

RSA (REPUBLIC OF SOUTH AFRICA). 2000. Local Government: Municipal Systems Act, Act 32 of 2000. Pretoria: Government Printers.

RSA (REPUBLIC OF SOUTH AFRICA). 2013. Spatial Planning and Land Use Management Act, Act 16 of 2013. Pretoria: Government Printers.

SALKIN, P.E. 2006. Intersection between environmental justice and land use planning. Planning \& Environmental Law, 58(5), pp. 3-9. https://doi.org/10.1080/15480755.2006 .10394345

SALMINEN, A. \& LEHTINEN, S. 1982. 'Hallintotiede ja vertaileva tutkimus' (Administrative Science and Comparative Study). In: Larimo, J. (Ed). Proceedings of the University of Vaasa. Research Papers, No. 86.

SCHLOSBERG, D. 2004.

Reconceiving environmental justice: Global movements and political theories. Environmental Politics, 13(3), pp. 517-540. https://doi. org/10.1080/0964401042000229025

SCHLOSBERG, D. 2013. Theorising environmental justice: The expanding sphere of a discourse. Environmental Politics, 22(1), pp. 37-55. https://doi.org /10.1080/09644016.2013.755387

SEN, A. 2009. The idea of justice. London: Penguin Books.
SHARMA, S.K., DESWAL, S. \& JOHN, S. 2009. Collaborative planning: A tool for environmental management in infrastructural development. In: Proceedings of the International Conference on Energy and Environment, 19-21 March 2009, Chandigarh, India: National Institute of Technology, pp. 273-277.

SOJA, E.W. 2009. The city and spatial justice. Paper presented at the International Conference Spatial Justice, 12-14 March 2008, University of Paris, Nanterre.

SOLITARE, L. 2005. Prerequisite conditions for meaningful participation in brownfields redevelopment. Journal of Environmental Planning and Management, 48(6), pp. 917-935. https://doi. org/10.1080/09640560500294475

STANLEY, A. 2009. Just space or spatial justice? Difference, discourse, and environmental justice. Local Environment: The International Journal of Justice and Sustainability, 14(10), pp. 999-1014.

SPIRN, A.W. 2005. Restoring Mill Creek: Landscape literacy, environmental justice and city planning and design. Landscape Research, 30(3), pp. 395-413. https://doi. org/10.1080/01426390500171193

STRAUSS, A. \& CORBIN, J. 1998. Basics of qualitative research techniques and procedures for developing grounded theory. London: Sage.

STUBBS, A. 1981. The pros and cons of consequentialism. Philosophy, 56(218), pp. 497-516. https://doi. org/10.1017/S0031819100050543

SUDONIENĖ, V. \& MATONIENÈ, D. 2009. Land use planning in Lithuania and in the United States. In: Proceedings of the $4^{\text {th }}$ International Scientific Conference Rural

Development (volume 4, book 1), 15-17 October 2009, Akademija, Kaunas region, Lithuania. Lithuania: Lithuanian University of Agriculture, pp. 153-160.

TILAKI, M.J.M., ABDULLAH, A., BAHAUDDIN, A. \& MARZBALI, M.H. 2014. An evaluation to identify the barriers to the feasibility of urban development plans: Five decades of experience in urban planning in Iran. Journal of Urban and Environmental Engineering, 8(1), pp. 38-47. https://doi. org/10.4090/juee.2014.v8n1.038047

TILLNER, S. 2013. Incremental planning - cooperative scenario and/ or masterplan? Long- and short-term planning horizon of urban design projects within the existing urban fabric. Analysis of projects in Vienna and Switzerland with regard to the factors triggering varying planning times. In: Schrenk, M., Popovich, V.V., Zeile, P. \& Elisei, P. (Eds). Proceedings of the 18th International Conference on Urban Planning, Regional Development and Information Society (REALCORP), 2024 May 2013, Rome, Italy. SchwechatRannersdorf: Medieninhaber und Verleger, pp. 419-428.

TODES, A. 2004. Regional planning and sustainability: Limits and potentials of South Africa's integrated development plans. Journal of Environmental Planning and Management, 47(6), pp. 843-861. https://doi. org/10.1080/0964056042000284866

TODES, A., KARAM, A., KLUG, N. \& MALAZA, N. 2010. Beyond master planning? New approaches to spatial planning in Ekurhuleni, South Africa. Habitat International, 34, pp. 414-420. https://doi.org/10.1016/j. habitatint.2009.11.012

TYLER, T.R. 1988. What is procedural justice? Criteria used by citizens to assess the fairness of legal procedures. Law \& Society Review, 22(1), pp. 103136. https://doi.org/10.2307/3053563

URKIDI, L. \& WALTER, M. 2011. Dimensions of environmental justice in anti-gold mining movements in Latin America. Geoforum, 42(6), pp. 683-695. https://doi.org/10.1016/j. geoforum.2011.06.003

VAN DER MERWE, C.D. 2009. Environmental justice - a new theoretical construct for urban renewal? The case of heritage at Constitution Hill, Johannesburg. Environmental Justice, 2(1), pp. 25-33. https://doi. org/10.1089/env.2008.0532

WATSON, V. 2003. Conflicting rationalities: Implications for planning theory and ethics. Planning Theory \& Practice, 4(4), pp. 395-407. https://doi. org/10.1080/1464935032000146318

WHYTE, K.W. 2011. The recognition dimensions of environmental justice in Indian country. Environmental Justice, 4(4), pp. 199-205. https://doi. org/10.1089/env.2011.0036

YINGJIE, H., DE ROO, G. \& BIN, L. 2013. 'Communicative turn' in Chinese spatial planning? Exploring possibilities in Chinese contexts. Cities, 35, pp. 42-50. https://doi.org/10.1016/j. cities.2013.05.001 